\title{
Marin-Amat syndrome: a case of acquired facial synkinesis
}

\author{
Abhishek Malhotra
}

Department of Neurology, Geelong Hospital, Geelong, Victoria, Australia

\section{Correspondence to} Dr Abhishek Malhotra, dr.malhotra@gmail.com
To cite: Malhotra A. BMJ Case Rep Published online: [please include Day Month Year] doi:10.1136/bcr-2013010030

\section{DESCRIPTION}

Marin-Amat syndrome is a form of acquired facial synkinesis manifesting as involuntary eyelid closure on jaw opening. This often occurs following the aberrant regeneration of the facial nerve after a peripheral facial palsy. ${ }^{1}$ It is less recognised form of oculofacial synkinesis than the more well-known Marcus-Gunn-jaw-winking phenomenon (MGJWP), wherein there is eyelid elevation on the ipsilateral contraction of the lateral or medial pterygoid muscle. ${ }^{12}$ The synkinetic movements in Marin-Amat syndrome are opposite to that seen in MGJWP. ${ }^{1}$ This had sometimes led to a confusion in the literature regarding another form of synkinesis called the inverse Marcus-Gunn phenomenon/syndrome. The mechanism of synkinesis are different in both, and the term inverse Marcus-Gunn syndrome should be reserved only for a congenital lesion, where the mechanism of lid closure is because of inhibition of the levator palpebrae superioris rather than orbicularis oculi contraction as seen in Marin-Amat syndrome (figure 1). ${ }^{12}$ Most patients with minor cosmetic deformity do not need treatment, but in some cases botulinum toxin or eyelid surgery may be helpful. ${ }^{3}$

We describe a case of Marin-Amat syndrome in a woman who developed right-sided Bell's palsy 9 years ago. She made a reasonable recovery but persists of have synkinesis with jaw opening causing right eyelid closure. This has caused cosmetic disfigurement and she feels awkward in social gatherings. She is self-conscious when her photographs are taken and tends to turn her head to the left to avoid presenting the right side of face.

\section{Learning points}

- Marin-Amat syndrome is a form of acquired oculofacial synkinesis due to aberrant regeneration of facial nerve manifesting as involuntary eyelid closure on jaw opening.

- The eyelid closure occurs due to orbicularis oculi contraction rather than inhibition of levator palpebrae superioris as is seen in inverse Marcus-Gunn syndrome.

- There can be cosmetic disfigurement and in some cases treatment with botulinum toxin injections or eyelid surgery may be helpful.

\section{Competing interests None.}

Patient consent Obtained.

Provenance and peer review Not commissioned; externally peer reviewed. 


\section{REFERENCES}

1 Rana PV, Wadia RS. The Marin-Amat syndrome: an unusual facial synkinesia. J Neurol Neurosurg Psychiatry 1985;48:939-41.
2 Davis G, Chen C, Selva D. Marcus Gunn syndrome. Eye (Lond) 2004:18:88-90.

3 Lai CS, Lu SR, Yang SF, et al. Surgical treatment of the synkinetic eyelid closure in Marin-Amat syndrome. Ann Plast Surg 2011;67:498-501.

Copyright 2013 BMJ Publishing Group. All rights reserved. For permission to reuse any of this content visit http://group.bmj.com/group/rights-licensing/permissions.

BMJ Case Report Fellows may re-use this article for personal use and teaching without any further permission.

Become a Fellow of BMJ Case Reports today and you can:

- Submit as many cases as you like

- Enjoy fast sympathetic peer review and rapid publication of accepted articles

- Access all the published articles

- Re-use any of the published material for personal use and teaching without further permission

For information on Institutional Fellowships contact consortiasales@bmjgroup.com

Visit casereports.bmj.com for more articles like this and to become a Fellow 